\title{
Analysis of 7th Grade Student's Mathematical Understanding in Solving Sets Problem: A Perspective of Skemp Understanding Theory
}

\author{
Intan Rachmawati ${ }^{1, *}$ Budi Usodo ${ }^{2}$ Sri Subanti ${ }^{3}$ \\ ${ }^{1}$ Postgraduate of Mathematics Education, Faculty of Teacher Training and Education, Universitas Sebelas \\ Maret, Surakarta, Indonesia \\ ${ }^{2}$ Department of Mathematics Education, Universitas Sebelas Maret, Surakarta, Indonesia \\ ${ }^{3}$ Department of Mathematics and Natural Sciences, Universitas Sebelas Maret, Surakarta, Indonesia \\ *Corresponding Author. Email: intanrachmawati98@student.uns.ac.id
}

\begin{abstract}
The key word to success in learning mathematics is mathematical understanding. Mathematical understanding is very important because it can train students' ability to relate one concept to another. Skemp states that understanding was divided into two types, there were instrumental understanding and relational understanding. The purpose of this study was to describe the mathematical understanding of 7 th grade junior high school students in solving set problems based on Skemp's theory of understanding. The type of research used is qualitative research with a descriptive approach. Subject selection using purposive sampling technique. The subjects in this study were three grade VII students who were divided into three categories of high, medium and low ability. The data were obtained using a mathematical understanding test and interviews. Data analysis was carried out in stages, there were data collection, data reduction, data analysis, and drawing conclusions. The results showed that a student with high ability has good mathematical understanding because she can fulfill most of the indicators of understanding, where she being able to understand the questions well so that she can analyze the questions and solve the questions given. Meanwhile, students with moderate and low abilities have poor understanding of mathematics, where students cannot understand the purpose of the problem properly. The indicators that are met are only indicators of grouping objects based on needs and providing examples of concepts.
\end{abstract}

Keywords: Mathematical understanding, Skemp understanding, Set problem.

\section{INTRODUCTION}

Mathematics is a science that studies relations, finds and solves a problem that doesn't only focus on calculations. Mathematics can be viewed as a learning process that requires focus and deeper understanding, not just remembering or memorizing [1]. Of course, the desired understanding is not only about mathematical rules and how to use them, but also understanding the reasons that underlie the truth of these rules. Thus, the key word that becomes the beginning of success in learning mathematics is mathematical understanding.

Mathematical understanding is an ability that is considered good as a process to achieve an understanding and is used as a result of achieving understanding [2]. Students who have a good mathematical understanding must be able to understand mathematical concepts easily which has an impact on improving mathematics learning outcomes. Therefore, mathematical understanding is very important because it can train students' ability to relate one concept to another [3].

One of the theories of mathematical understanding that teachers can use to differentiate students who really understand and students who don't actually understand a concept is Skemp's theory of understanding [4]. Skemp differentiate two kinds of understanding based on students' abilities, namely instrumental understanding and relational understanding. Instrumental understanding occurs when students are only able to solve problems correctly by applying memorized rules without 
knowing the reasons for using these rules. On the other hand, relational understanding occurs when students are able to solve problems that correctly apply the rules with the correct processing process and are able to explain the reasons for the answers. Based on this understanding, Skemp categorizes understanding into more specific ones. Relational understanding is the most appropriate category of understanding in understanding a concept [5].

There are several characteristics of students with instrumental understanding and relational understanding. Students with relational understanding have characteristics, namely 1) can explain a concept used "why"; 2) reflect before acting; 3) will give the answer in the end; 4) can adapt to any task, using prior knowledge; 5) strive to understand; and 6) enjoy doing math problems for their own sake [6]. In line with this, relational understanding also focuses not only on a procedure to arrive at the required answer, but can also improve students' mathematical understanding [7]. It is different with the characteristics of students who have instrumental understanding, namely 1 ) unable to explain a concept used "why"; 2) can provide direct answers to certain questions; 3 ) sometimes unable to make progress; 4) more likely to memorize; 5) depending on the example explained by the teacher; and 6) can't find math fun [6].

There are seven indicators of understanding according to Skemp, namely: 1) students' ability to classify objects based on needs that can form a concept; 2) students' ability to apply concepts algorithmically; 3) students' ability to give examples of a concept; 4) the ability to repeat the concepts learned; 5) students' ability to provide some mathematical concepts; 6) students' ability to correlate several mathematical concepts; 7) the ability to develop the necessary requirements and adequate requirements of certain concept [8].

Mathematical understanding is a very important ability that must be mastered by students because it can train students' abilities in connecting a mathematical concept with other concepts [3]. Understanding concepts is a key aspect of learning because it can help students understand a concept that is not only to be remembered separately [9]. Therefore, if the knowledge of mathematical ideas or ideas that students have is wider, the more benefits they will have in solving the mathematical problems they are facing.

In the fact, not all students have a good mathematical understanding. Students with low abilities have difficulty in several indicators of Skemp's mathematical understanding [8]. It is quite difficult to find students who have relational understanding compared to students who have instrumental understanding, where only one student is found who has relational understanding [10]. In addition, four indicators of instrumental and relational understanding abilities, students who achieve the first indicator are only $10 \%$ and $5 \%$ are almost right, while $85 \%$ of other students do not achieve these indicators. However, it is different for the second, third and fourth indicators where none of the students managed to achieve it [11]. Based on these studies, it is stated that not all students have a good mathematical understanding, so this indicates that there are difficulties experienced by students in mathematical understanding.

One of the mathematics lessons that involve understanding concepts, procedures, and computations that can train students' ability to understand a concept and can relate one concept to another is a set. The set material is one of the materials taught in class VII Islamic Junior High School. The reason the researcher chose the set material because this material is one of the basic materials that contains a lot of symbols, notations, and diagrams, so to understand the set material requires a good mathematical understanding. Likewise, the results of interviews with teachers, it was also revealed that students' knowledge of the set material is still not good, where students are still wrong in using set notation, students have difficulty converting story questions into mathematical sentences, and are confused about answering questions by linking several set concepts. The novelty in this research is the material used for research, namely the set material and also the students who are respondents are students from Islamic boarding schools. This is used as a novelty because in similar studies no one has investigated these two things. Therefore, this study aims to describe students' mathematical understanding in solving set problems based on Skemp's theory of understanding.

\section{RESEARCH METHODOLOGY}

The type of research used the qualitative research with a descriptive approach. This study aims to describe students' mathematical understanding. The analysis is based on the results of students' work in solving mathematical understanding problems on set material based on Skemp's theory of understanding and interview results. Subject selection using purposive sampling technique that was the determination with certain considerations and mathematics teachers' recommendation. The subjects 
in this study were three grade VII D students of MTs Darul Aman Mataram which were divided into three categories based on academic ability; high, moderate and low abilities as well as the consideration of the teacher. The grouping of students' abilities based on the results of the daily test scores with the level of mathematical ability [12]. The data in this study were obtained using a mathematical understanding test and interviews.

The data validity technique is carried out in stages, include preparation, implementation, data collection, and analysis, as well as report preparation. Preparation stage, includes understanding mathematical concepts, studying set theories, researchers prepare themselves as the main instrument, prepare students as supporters in expressing mathematical understanding, conduct preliminary research with assistance instruments sourced from textbooks that have been validated by the validator.

The instrument was then used as a data collection tool. Then, for the data collection and analysis stage, the activities include selecting research subjects, giving test instruments, and conducting interviews with students' research subject. Data then analyzed using the theory proposed by expert. After that, proceed with the writing of the report. The validity of the data in this study was carried out based on triangulation method and time. Triangulation is data collection with several methods such as interviews and observations, while time triangulation means comparing and analyzing data re-examine the level of confidence of the information obtained in the different time. Data analysis includes data reduction, presentation of data, and drawing conclusions.

\section{RESULT AND DISCUSSION}

After grouping based on students' mathematical abilities, it was found that from 39 students there were 9 students in the high ability category, 26 students in the moderate ability category, and 4 students in the low ability category. After being grouped, one student is selected in each category, including student S1 with high ability, student S2 with moderate ability, and student S3 with low-ability.

Indicators of mathematical understanding used in this study, namely: 1) students' ability to classify objects based on needs that can form a concept; 2) students' ability to apply concepts algorithmically; 3 ) students' ability to give examples of a concept; 4) the ability to repeat the concepts learned; 5) students' ability to provide some mathematical concepts; and 6) students' ability to correlate some mathematical concepts. These indicators are used as the basis for the preparation of questions and are used to conduct analysis.

Based on the data analysis, we classified the results into two parts, namely test result data and student interview data. Students' mathematical understanding is described based on test results in solving set questions and interview results. The process of students' mathematical understanding is explained in the following section.

Based on student responses, the three students have different understandings of the set material.

\section{Question 1:}

Is the following statement a set? If so, give your reasons! If false, give another example that belongs to the set!

a. A collection of intelligent students.

b. A group of students whose height is above $160 \mathrm{~cm}$.

Answer:

b. kumpulan siswa yg cerdas
= bukan termasuk himpunan
Contoh lainnya misolnya i
- kumpulan siswa yang perempuan
d. kumpulan siswa yg tingginy diatas
$160 \mathrm{~cm}=$ Termasuk himpunan karena
definisinya jelas

Figure $1 \mathrm{~S} 1$ answer of question 1.

Figure 1, it is assumed that $\mathrm{S} 1$ knows the examples that belong to the set and not the set. The student's answer number $1 \mathrm{a}$ is that the statement is not a set and she can give a statement that belongs to the set correctly. Next, S1 replied that statement number $1 \mathrm{~b}$ was included in the set and she was able to give the reason.

Based on the results of the interview with S1, she is able to give reasons that the statement in number 1a is not a set. Then she refuted the statement by giving another example which was included in the set, namely a collection of female students with their reasons.

The same likewise with number $1 \mathrm{~b}, \mathrm{~S} 1$ was able to give reasons for the statement including the set even though she was still in doubt. This is because the student's height in the statement has been clearly determined and is given a height limit above $160 \mathrm{~cm}$ so that members can be determined. This shows that 
S1 understands the difference between examples that include sets and non-sets with the reasons for that. Based on the discussion regarding answer number 1 , it appears that $\mathrm{S} 1$ has a good understanding of indicators 1 and 3, namely student is able to classify objects based on needs that can form a concept and are able to provide examples of a concept.

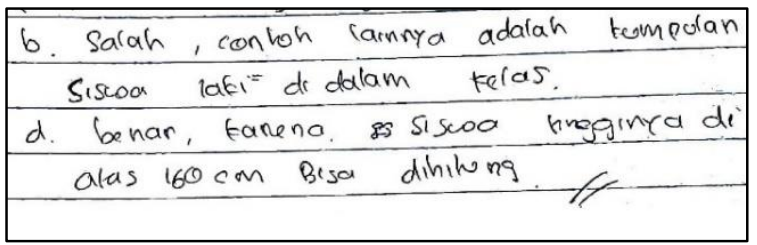

Figure 2 S2 answer of question 1.

Figure 2, it is assumed that S2 know examples that belong to sets and not sets. S2 answered that statement number 1a was wrong and gave another example that included the set. Then, she also wrote that number $1 \mathrm{~b}$ was including in the set along with the reasons.

Based on the results of the interview with S2, it can be seen that she can understand the meaning of the question 1. S2 is sure that answer she wrote in number $1 \mathrm{a}$ is correct. Then, to refute statement number $1 \mathrm{a}$, she gave another example that was included in the set, namely a collection of male students in the class and was able to explain the reasons for using the example.

The same to answer number $1 \mathrm{~b}, \mathrm{~S} 2$ is able to provide an explanation of the statement that is believed to be the set. She explained that the statement can be clearly defined and the members can be determined with certainty. Based on the opinions expressed by S2, this indicates that S2 have met indicator 3, which is able to provide examples of a set concept. In addition, S2 are able to classify objects based on needs that can form a concept, so that they have met indicator 1 .

B. Bukan himponan
d. Termasuf himponan
contoh bin:
kumpulan siswa pereandoan

Figure 3 S3 answer of question 1.

Figure 3, it is assumed that S3 know example that belong to sets and not sets. S3 wrote down answer number 1a instead the set and gave another example that was included in the set. Next, for answer number $1 \mathrm{~b}$, he wrote that the statement included the set, but was not accompanied by a reason.
Based on the results of the interview with $\mathrm{S} 3$, it appears that he is confused, has difficulty answering, and doesn't remember the material he has studied well. It only remembers to distinguish examples that belong to the set, if the members can be determined, while the examples that are not the set if the members cannot be determined. In answering question number 1a, he said that the statement was not a set and was able to give other examples that included the set. But he was not sure of the answer and didn't know the reason for writing the example.

Furthermore, $\mathrm{S} 3$ could not give a reason for answer $1 \mathrm{~b}$, because he didn't remember well the material he had studied. So, he answered the question by guessing. Based on this, S3 can be said to have met indicator 3, namely students are able to provide examples of a concept. However, it does not meet indicator 1 because it has not been able to classify objects based on needs that can form a concept.

Question 2:

A total of 20 teenagers were asked about their preferences for futsal and soccer. The survey results show that 5 people dislike both, 3 people like both, 7 people like futsal, and 11 people like soccer. How many people only like exactly one of the two?

Answer:

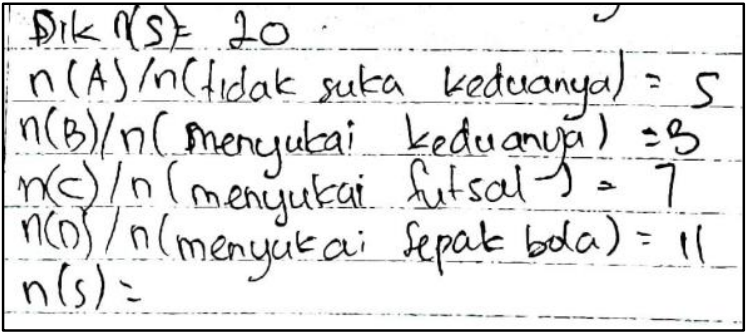

Figure $4 \mathrm{~S} 1$ answers of question 2.

Figure 4, it is assumed that S1 don't understand the purpose of question number 2. This can be seen from the answer of student S1 who have not finished working. In addition, S1 only write down the information she knew. In addition, she is still wrong in writing the symbols for the number of members in the set operation.

Based on the results of the interview with S1, it can be seen that S1 don't understand what is being asked the question 2. S1 only wrote down the information he knew without writing down what was asked of the question, because she don't know the mathematical symbols. S1 admitted that she still remembers writing the symbols for intersection, union, and complement on the set, but on the contrary. She couldn't correctly 
name the symbol of many members who like both or $\mathrm{n}(\mathrm{A} \cap \mathrm{B})$ and the symbol of many members who don't like both or $n(A \cup B)^{c}$. In fact, from this statement he did not understand and did not remember well the symbols of the set operation.

In addition, $\mathrm{S} 1$ did not answer the question until it was finished because he did not understand the purpose of the question 2 and did not know the steps for solving it. This shows that S1 don't meet indicator 4 , and indicator 6 which is sequentially not able to repeat the concepts that have been studied related to intersection, combinations, and complements in sets, and are not able to correlate some mathematical concepts.

Lacoab: \begin{aligned} &$A B^{c}=5 \\ &$\hline$A \cap B=3 \\ &$\hline$A=7 \\ &$\hline$B=11 \\ &$\hline$S=20 \\ &$\hline\end{aligned}

Figure 5 S2 answer of question 2.

Figure 5, it is assumed that S2 don't understand the purpose of question number 2 . She didn't answer the question until it was finished and only wrote information that was known. The answer to number 2 also shows that S2 still wrote the wrong symbol in determining the number of members in the set operation.

Based on the results of the interview with S2, she provides information that according to her memory the writing of the symbol of many members who don't like the two is $\mathrm{AB}^{\mathrm{c}}$. In addition, she stated that she still remembers writing the symbols for intersection, union, and complement in sets, but the opposite is true. She doesn't understand the set operation material well. And lastly, she didn't answer the question until the end because she didn't know the formula or steps in solving the problem.

Based on this, S2 may not understand the concept of set operations well. Therefore, the researcher indicated that $\mathrm{S} 2$ degree student did not meet indicator 4 , and indicator 6 , respectively, that the student had not been able to repeat the concepts they had learned regarding intersection, combinations, or complements on set story questions, and were unable to correlate some mathematical concepts.

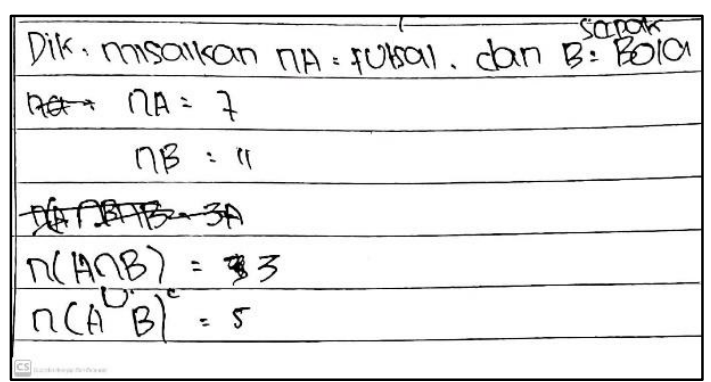

Figure 6 S3 answer of question 2.

Figure 6, it is assumed that S3 don't understand question number 2 well. S3 write down information that is known but is incomplete and there are errors. $\mathrm{S} 3$ also didn't answer the question until it was finished.

Based on the results of the interview with S3, he didn't answer question until it was finished, because he didn't know how to solve it.

In addition, he wrote the correct answer regarding the symbols of many members who like both or $\mathrm{n}(\mathrm{A} \cap$ $B)$, and the symbol of many members who dislike both or $\mathrm{n}(\mathrm{A} \cup \mathrm{B})^{\mathrm{c}}$. He knew the symbols of the intersection and union but only vaguely remembered them. In other words, he still didn't understand the concept of set well. Next, he doesn't understand the problem well and doesn't know the steps for solving question 2 . Thus, S3 didn't meet indicator 4, and indicator 6, which is not yet able to repeat the concepts that have been learned, and unable to correlate some mathematical concepts.

Question 3:

Given: $S=\{1,2,3,4,5,6,7,8,9,10\}, A=\{1,2,3,4$, $5\}, B=\{4,5,6,7,8\}$, and $C=\{3,5,7,9\}$. Define,
a. $(B-C) \cap A$
b. $\quad A^{c} \cup(B \cap C)$

Answer:

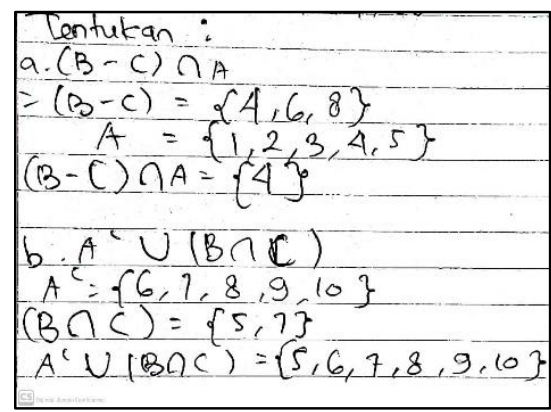

Figure $7 \mathrm{~S} 1$ answer of question 3.

Figure 7, it is assumed that $\mathrm{S} 1$ understand question 3 well. S1 answered two questions correctly and wrote 
down answers for numbers $3 a$ and $3 b$ in stages according to her understanding.

Based on the results of the interview with $\mathrm{S} 1$, she understands the concepts of difference, complement, intersection, and combination in sets. $\mathrm{S} 1$ can define the difference between sets $\mathrm{A}$ and $\mathrm{B}$ which is the sum of all members of A but not members of B. However, she hasn't been able to illustrate question 3 using a Venn diagram, because she doesn't understand how to draw a Venn diagram and immediately answers. In fact, if she could provide some of her own concepts it would make it easier to answer questions.

Based on the discussion on answer number 3, S1 have met indicator 2, namely students are able to apply concepts algorithmically. However, on the other hand, it does not meet indicator 5, which is not yet able to provide some mathematical concepts.

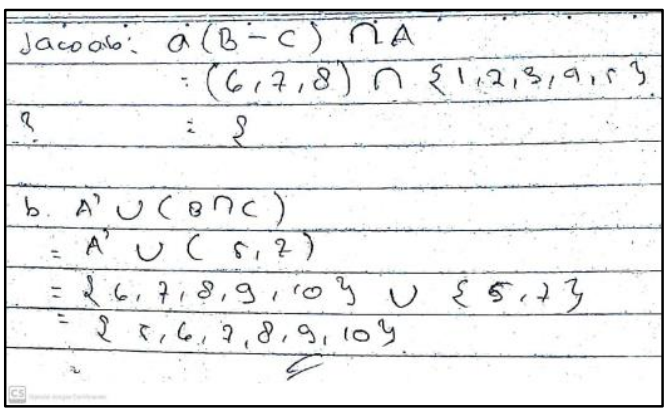

Figure 8 S2 answer of question 3.

Figure 8, it is assumed that $\mathrm{S} 2$ understand question number 3 . However, she only answered number $3 \mathrm{~b}$ correctly while number 3a wasn't solved.

Based on the results of the interview with $\mathrm{S} 2$, she understands the concepts of complement, intersection, and combination except the concept of difference in set. That's because she can't remember and understand well the definition of the difference in the set, so she can't solve question 3a. In addition, S2 hasn't been able to illustrate problem number 3 using a Venn diagram, because she doesn't know how to draw it. Therefore, the researcher indicated that the student degree student had met indicator 2, namely S2 were able to apply concepts algorithmically, but did not meet indicator 5, which was not yet able to provide some mathematical concepts.

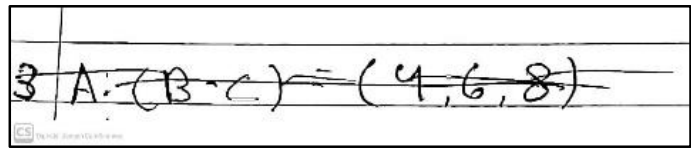

Figure $9 \mathrm{~S} 3$ answer of question 3.
Figure 9, it is assumed that S3 don't understand question 3. He didn't answer questions 3. Based on the results of the interview with S3, he only knows the concepts of intersection, union on sets and he didn't answer the question 3. That's because he is still hesitating in solving it, in other words he can't remember the concept of the set well. In addition, he can't illustrate the question 3 using a Venn diagram, because he doesn't know how to operate and only knows the drawing. Thus, it can be said that student S3 do not meet indicators 2 and 5, namely, S3 are not able to apply concepts algorithmically, and are not able to provide some mathematical concepts. So it can be said that S3 have less mathematical understanding.

Based on the description above, it can be seen that $\mathrm{S} 1$ has a high ability to have a good mathematical understanding in solving set problems. However, the different situations experienced by $\mathrm{S} 2$ with moderate ability and S3 with low ability show a lack of mathematical understanding in solving set problems. The students' lack of mathematical understanding can be seen from several indicators of understanding based on Skemp's theory that don't meet, such as the lack of understanding in repeating concepts, linking several mathematical concepts, providing several concepts, and lack of understanding how to apply concepts algorithmically. Then, on the results of interviews with researchers who asked several short questions, students didn't understand the concept because they didn't remember the formula and didn't remember the concepts well that could be used to answer the questions given.

As well, analysis of student work on the answer sheet, there are half and almost all indicators of mathematical understanding not fulfilled. Evidence of student error on the answer sheet is supported by the results of interviews with student. In this case, if it is associated with Skemp's theory of understanding, then the student's inability to meet all indicators mathematical understanding can provide evidence that student S1, S2 and S3 included in the category of instrumental understanding. These results indicate that students' mathematical understanding needs to be improved.

Teachers have an important role in overcoming these problems, because teachers are very influential on the success of learning. In line with the opinion of Kaya and Aydin said that teachers have a key role in creating a communicative classroom environment [13]. The creation of a communicative class is 
expected to be able to bring up the development of students' mathematical understanding [14].

\section{CONCLUSION}

Based on the results of research and discussion, it can be concluded that high-ability students have good mathematical understanding because they are able to meet the indicators of classifying objects based on needs that can form a concept, are able to apply concepts algorithmically and provide examples of concepts. This is shown by the students being able to understand the questions well so that she can analyze the questions and solve the questions given. When solving problems, she is able to answer them well and problems related to the set can be solved correctly even though they are not neat in writing. Then, she knows when to use a concepts and utilizes the knowledge needed to solve problems. Although sometimes she makes mistakes, but she can give logical arguments about the procedure even though she doesn't answer perfectly.

Students with moderate and low ability have poor mathematical understanding because they only meet less than a few of the indicators of understanding. They couldn't solve problems well because they didn't know the steps to answer the questions given. They don't know when to apply certain concepts, so they are prone to failure in completing them. Likewise, students don't understand the information stated in the problem and can't operate the concept of operations on sets properly. Several inhibiting factors students' mathematical understanding is students do not understand the material well, students only memorize the rules of the concepts that have been studied without know ing the reasons for using these rules, so it is easy to forget formulas, and students do not know the steps that will be used in solving problems. These results indicate that students' mathematical understanding needs to be improved.

\section{REFERENCES}

[1] W. A. Brownell, "The Progressive Nature of Learning in Mathematics," Math. Teach., vol. 100, pp. 26-34, 2007.

[2] J. Cai and M. Ding, "On mathematical understanding: perspectives of experienced Chinese mathematics teachers," J. Math. Teach. Educ., vol. 20, pp. 5-29, 2015.

[3] M. Dini, T. T. Wijaya, and A. I. Sugandi, "Pengaruh Self Confidence Terhadap Kemampuan Pemahaman Matematik Siswa Smp,” J. SILOGISME, vol. 3, pp. 1-7, 2018.
M. Annisa, H. Aan, and H. Tatang, "Analysis of Students Mathematical Understanding Viewed from Visual and Visual-Auditory Learning Styles," Int. Semin. STEMEIF (Science, Technol. Eng. Math. Learn. Int. Forum), pp. 386-393, 2019.

[5] R. R. Skemp, "Relational Understanding and Instrumental Understanding," Math. Teach. Middle Sch., vol. 26, no. 3, pp. 9-15, 1978.

[6] E. Maclellan, “Articulating 'understanding': Deploying mathematical cognition," Scottish Educ. Rev., vol. 46, no. 2, pp. 73-89, 2014.

[7] V. Napaphun, "Relational Thinking: Arithmetic in order to Promote Algebraic Thinking," J. Sci. Math. Educ. Southeast Asia, vol. 35, no. 2, pp. 84-101, 2012.

[8] R. H. Kuncorowati, M. Mardiyana, and D. R. S. Saputro, "The Analysis of Student's difficulties Based on Skemp's Understanding Theorem at The Grade VII in Quadrilateral Topic," Int. J. Sci. Appl. Sci. Conf. Ser., vol. 2, no. 1, pp. 318-328, 2017.

[9] K. Winarto, U. Ardiyansyah, A. Wilujeng, and I. Sukardiyono, "Pocket Book Based on Comic to Improve Conceptual ...," Int. J. Instr., vol. 11, no. 4, pp. 889-900, 2018.

[10] P. Mytra and A. Heriyanti, "Deskripsi Pemahaman Materi Pecahan Siswa Kelas Vii Smp Negeri 1 Salomekko," JTMT J. Tadris Mat., vol. 1, no. 1, pp. 1-6, 2020.

[11] R. Tianingrum and H. N. Sopiany, "Analisis Kemampuan Pemahaman Matematis Siswa SMP pada Materi Bangun Ruang Sisi Datar," Pros. Semin. Nas. Mat. dan Pendidik. Mat., pp. 440-446, 2017.

[12] F. E. Men, "Proses Berpikir Kritis Siswa Sma Dalam Pengajuan," J. Pendidik. dan Kebud. Missio, vol. 9, no. 1, pp. 35-42, 2017.

[13] D. Kaya and H. Aydin, "Elementary mathematics teachers' perceptions and lived experiences on mathematical communication," Eurasia J. Math. Sci. Technol. Educ., vol. 12, no. 6, pp. 1619-1629, 2016.

[14] C. Chasanah, Riyadi, and B. Usodo, "Analysis of Written Mathematical Communication Skills of Elementary School Students," Atl. Press, vol. 397, pp. 648-656, 2020. 